\title{
Asosiasi Marka Genetik dengan Pertambahan Bobot Badan Sapi Madura di Pamekasan
}

\author{
Suyadi ${ }^{1}$, Isnaini $\mathbf{N}^{1}$, Rahayu S. ${ }^{2}$ dan Y. Nurpah ${ }^{3}$ \\ ${ }^{1}$ Staff Member of Faculty of Animal Husbandry University of Brawijaya, Malang \\ ${ }^{2}$ Staff Member of Faculty of Natural and Mathematics Sciences University of \\ Brawijaya, Malang \\ ${ }^{3}$ Alumni of Faculty of Animal Husbandry University of Brawijaya, Malang
}

\begin{abstract}
Characteristic of DNA markers may be able to be used as useful and efficient tool to select merit animal from a population. In order to Madura cattle, growth rate is one of important traits should be considered. The aim of this study was to evaluate the association between the characteristic of DNA marker of candidate gene for growth hormone $(\mathrm{GH})$ and growth rate of Madura cattle. A number of 10 female Madura cattle selected from 40 animals in average of about 18 months old were used as sample. The animal was weighed twice using electronic balance at the interval time of two months. At the simultaneous time to the animal weighing the blood sample was collected via vena jugularis $6 \mathrm{ml}$ of each for DNA source. The blood sample was dropped ito polypropylene tubes containing EDTA for anti coagulant agent. DNA was isolated from leucocyte cells in the blood using salting out as standard method. PCR technique was used for amplifying the DNA using GH primer (forward: 5'TAGGGAGGTGGAAAATGGA-3' and reverse: 5'-GACACCTAGACAATGCG-3'). DNA polymorphism of GH gene was detected using RFLP technique by digesting the PCR-product DNA with HaeIII enzyme at position of GG*CC. The results showed that amplified DNA with this primer showed a single band of $450 \mathrm{bp}$. Restriction of DNA with HaeIII enzyme resulted 4 haplotypes of uncut fragment , 2 fragments ( $2 \mathrm{a}$ and $2 \mathrm{~b}$ ), 3 fragments ( $3 \mathrm{a}$ and $3 \mathrm{~b}$ ) and 5 fragments at the position of $125 \mathrm{bp}, 200 \mathrm{bp}, 275 \mathrm{bp}$ and 450 bp. According to the data analysis, the non significant association was shown between specific genetic polymorphism and growth rate in this cattle.
\end{abstract}

Key words: DNA marker, GH gene, growth rate, Madura cattle

\section{PENDAHULUAN}

Sapi Madura merupakan salah satu ternak lokal Indonesia yang memiliki ciri spesifik yang kemungkinan besar tidak dimiliki oleh ternak eksotik lainnya. Diantara ciri tersebut adalah ketahanan yang tinggi terhadap kondisi lingkungan tropis dengan suhu dan kelembaban harian tinggi, kondisi pakan kualitas rendah serta cekaman terhadap berbagai parasit (Suyadi, 2005).
Keyakinan saat ini adalah bahwa performans produksi sapi Madura selalu menurun dari tahun ke tahun yang disebabkan oleh menurunnya kualitas lingkungan untuk sapi bangsa ini dan kemungkinan terjadinya seleksi negatif yang berlansung di masyarakat sebagai akibat dua faktor utama yaitu (1) tidak adanya program breeding yang jelas dan ketat yang dapat diterapkan di masyarakat dan (3) pengetahuan dan kondisi sistem peternakan rakyat yang mengharuskan 
kenyataan ini terjadi (Suyadi et al., 2005). Untuk memperbaiki kinerja produksi sapi Madura, maka tidak ada pilihan lain kecuali dengan menerapkan seleksi yang terarah dan dilangsungkan secara kontinyu. Seleksi berdasarkan catatan individu ternak (sistem rekording) melalui pendekatan genetika kuantitatif telah terbukti mampu meningkatkan mutu genetik ternak serta produktivitasnya. Namun, metode ini memerlukan waktu yang sangat lama serta kecermatan dan kekomplekan sistem rekording. Di sisi lain, tidak menjangkau aspek genotip ternak yang mencerminkan potensi keunggulan genetiknya.

Seleksi berdasarkan marka genetik telah dipercaya dapat meningkatkan efisiensi dan percepatan pelaksanaan seleksi sehingga kemajuan genetik dapat ditingkatkan (Ge et al., 2001). Penelitian ini bertujuan untuk mengetahui asosiasi atau hubungan antara marka genetik pada gen pertumbuhan dengan pertambahan bobot badan (PBB) sapi Madura di wilayah Pamekasan.

\section{MATERI DAN METODE}

\section{Ternak dan Koleksi Sampel Darah}

Selama sekitar 2 bulan, sebanyak 35 ekor sapi Madura berumur sekitar 1 tahun di wilayah Pamekasan ditimbang bobot badannya dan bersamaan dengan waktu tersebut diambil sampel darah sekitar 6 $\mathrm{ml}$ per ekor. Darah ditampung dalam tabung propilen $15 \mathrm{ml}$ yang telah mengandung anti koagulan EDTA.

\section{Pemisahan Leukosit dan Isolasi DNA}

Sampel darah yang akan diteliti dipipeting sebanyak $3 \mathrm{ml}$ kemudian dimasukkan ke dalam tabung polipropilen $15 \mathrm{ml}$, tambahkan $9 \mathrm{ml}$ RBCs 1X, RBCs berfungsi sebagai pemecah sel darah merah, homogenkan dengan gerakan bolak-balik, diinkubasi pada suhu ruang selama 10 menit kemudian disentrifugasi pada $1500 \mathrm{rpm}$ selama10 menit, buang supernatan. Prosedur ini diulangi sebanyak 3 kali sampai pelet (endapan) berwarna putih. Pelet yang didapat merupakan limfosit (Robyt dan White, 1987).

Sel limfosit yang telah dipisahkan dari darah ditambah dengan $750 \mu \mathrm{l}$ Cell Lysis Solution (CLS), CLS berfungsi memecahkan dinding sel darah putih dan dinding intinya, dihomogenkan dengan cara pipetting kemudian diinkubasi pada suhu $37^{\circ} \mathrm{C}$ selama 15 menit. Tambahkan $500 \mu 1$ Protein Precipitation homogenkan dengan cara divortex, pindahkan ke dalam tabung appendorf 1,5 $\mathrm{ml}$, disentrifugasi $10000 \mathrm{rpm}$, selama 15 menit pada suhu $4^{\circ} \mathrm{C}$, pindahkan supernatan pada tabung appendorf baru, jangan sampai pelet ikut terambil. Supernatan pada tabung baru ditambah dengan protein precipitation sebanyak $500 \mu \mathrm{l}$, divortek, dan disentrifugasi (10000 rpm, 15 menit, suhu $\left.4^{\circ} \mathrm{C}\right)$. Supernatan dibagi dalam 3 buah appendorf baru, lakukan dengan hati-hati agar pellet tidak terambil. Pada setiap appendorf ditambahkan $1000 \mu \mathrm{l}$ etanol absolut dingin, campuran dihomogenkan dengan dibolak-balik 25 sampai 30 kali sampai terlihat benang DNA berwarna putih, kemudian diinkubasi pada refrigerator $4^{\circ} \mathrm{C}$ semalam. Keesokan harinya appendorf yang berisi cairan tersebut disentrifugasi $10000 \mathrm{rpm}$ selama 15 menit pada suhu $4^{\circ} \mathrm{C}$, buang supernatan yang terbentuk. Tambahkan $1000 \mu \mathrm{l}$ etanol $70 \%$ dingin, kocok sampai terlihat benang DNA 25-30 kali, disentrifugasi (10000 rpm, 15 menit, $4^{\circ} \mathrm{C}$ ), buang supernatan, dikering anginkan (oven pada suhu $37^{\circ} \mathrm{C}$, selama kurang lebih 30 menit). Apabila masih ada tabung yang basah keringkan dengan cotton bud, tambahkan TE buffer 
sebanyak $100 \mu \mathrm{l}$, simpan dalam freezer bersuhu $-20^{\circ} \mathrm{C}$ sampai akan digunakan.

\section{Amplifikasi DNA dengan Metode PCR}

Untuk mendapatkan fragmen DNA spesifik pertumbuhan dilakukan amplifikasi dengan menggunakan primer spesifik yaitu GHE5F sebagai forward dengan urutan basa 5'TAGGGGAGGGTGGAAAATGGA-3' dan GHE5R sebagai reverse dengan urutan basa 5'GACACCTACTCAGACAATGCG-3'.

Primer GHE5F dan GHE5R diadopsi dari Ge et al. (2003). Campuran reaksi terdiri dari 3,78 $\mu 1 \mathrm{dH}_{2} \mathrm{O} ; 0,11 \mu 1$ primer GHE5F; $0,11 \mu 1$ primer GHE5R; $5 \mu 1$ PCR mix dan $1 \mu \mathrm{l}$ DNA (volume campuran total $10 \mu \mathrm{l}$ ) dimasukkan ke dalam thin wall dengan urutan sesuai urutan penyebutan. Setelah campuran siap, thin wall dimasukkan ke dalam alat Thermal cyler biorad. Proses amplifikasi terdiri dari 31 siklus. Masing-masing siklus terdiri dari denaturasi template DNA pada suhu $94^{\circ} \mathrm{C}$ selama 60 detik, $58^{\circ} \mathrm{C}$ selama 45 detik dan $72^{\circ} \mathrm{C}$ selama 60 detik. Siklus diawali dengan hot start pada suhu $95^{\circ} \mathrm{C}$ selama 5 menit dan diakhiri dengan inkubasi pada suhu $72^{\circ} \mathrm{C}$ selama 7 menit, dilanjutkan suhu $37^{\circ} \mathrm{C}$ selama 5 menit (Ge et al., 2003).

Untuk melihat keberhasilan PCR dilakukan elektroforesis dalam gel agarosa $2 \%$, tegangan 110 Volt, diwarnai dengan ethidium bromide dan dievaluasi dengan $U V$ transiluminator. Gel agarosa $1 \%$ dibuat dengan melarutkan 0,3 gram bubuk agarosa ke dalam $15 \mathrm{ml}$ larutan TBE 1X di dalam Erlenmeyer. Selanjutnya larutan tersebut dipanaskan di dalam microwave oven untuk menghomogenkan agarosa, sambil sesekali digoyang sampai bening. Larutan dibiarkan sampai agak dingin kemudian ditambahkan ethidium bromide 0,5 $\mu 1$ dan digoyang untuk menghomogenkan.
Selanjutnya larutan dituangkan ke dalam cetakan yang telah dipasangi sisir pencetak. Setelah gel mengeras ditempatkan pada electroforesis chamber yang telah diisi buffer TBE 1X. kedalam setiap sumuran dimasukkan sample DNA sebanyak $3 \mu 1$ yang telah dicampur dengan $2 \mu \mathrm{l}$ loading dye. Alat elektroforesis kemudian dihubungkan dengan sumber listrik 110 volt lalu dihidupkan. Dan dibiarkan selama 30 menit. Selanjutnya gel diamati dengan UV transiluminator dan kemudian difoto dengan kamera polaroid. Keberhasilan amplifikasi dapat dilihat dengan adanya pita DNA pada gel agarosa dan besarnya DNA hasil amplifikasi diukur berdasarkan DNA marker.

\section{Pemotongan DNA oleh Enzim Restriksi Dengan Metode RFLP}

Untuk mengetahui adanya polimorfisme pada DNA marker kandidat gen pertumbuhan, dilakukan pemotongan DNA menggunakan enzim restriksi HaeIII, enzim HaeIII memiliki sisi pemotongan pada basa GG $\downarrow \mathrm{CC}$. Campuran reaksi terdiri dari $0,5 \mu \mathrm{l}$ deionized water steril $\left(\mathrm{dH}_{2} \mathrm{O}\right)$ dimasukkan ke dalam thin wall, ditambah buffer enzim sebanyak 1,2 $\mu$ l, DNA PCR produk sebanyak $3 \mu \mathrm{l}$, enzim restriksi HaeIII sebanyak 3,5 $\mu$ l dikocok pelan, kemudian diinkubasi dalam waterbath yang telah diatur pada suhu $37^{\circ} \mathrm{C}$ selama 3 jam. $37^{\circ} \mathrm{C}$ merupakan suhu dimana enzim dapat bekerja secara optimal.

Hasil pemotongan dengan teknik RFLP berupa beberapa fragmen DNA kemudian dielektroforesis dengan gel agarosa 2\%, diwarnai dengan ethidium bromide dan dievaluasi menggunakan UV transiluminator, DNA yang terekspresi didokumentasi dengan kamera polaroid.

Data hasil PCR-RFLP kemudian dianalisis secara deskriptif dan 
dihubungkan dengan data fenotipik Sapi Madura di Pamekasan.

\section{HASIL DAN PEMBAHASAN}

\section{DNA Hasil Amplifikasi}

DNA hasil isolasi diukur kemurnian dan konsentrasinya untuk mengetahui kelayakan sampel dan selanjutnya diamplifikasi dengan metode PCR menggunakan primer GHE5F sebagai forward

$\left(5^{\prime}-\right.$ TAGGGGAGGGTGGAAAATGGA-3') dan GHE5R sebagai reverse (5'GACACCTACTCAGACAATGCG-3') yang diadopsi dari Ge et al. (2003). Hasil amplifikasi ditunjukkan pada Gambar 1.

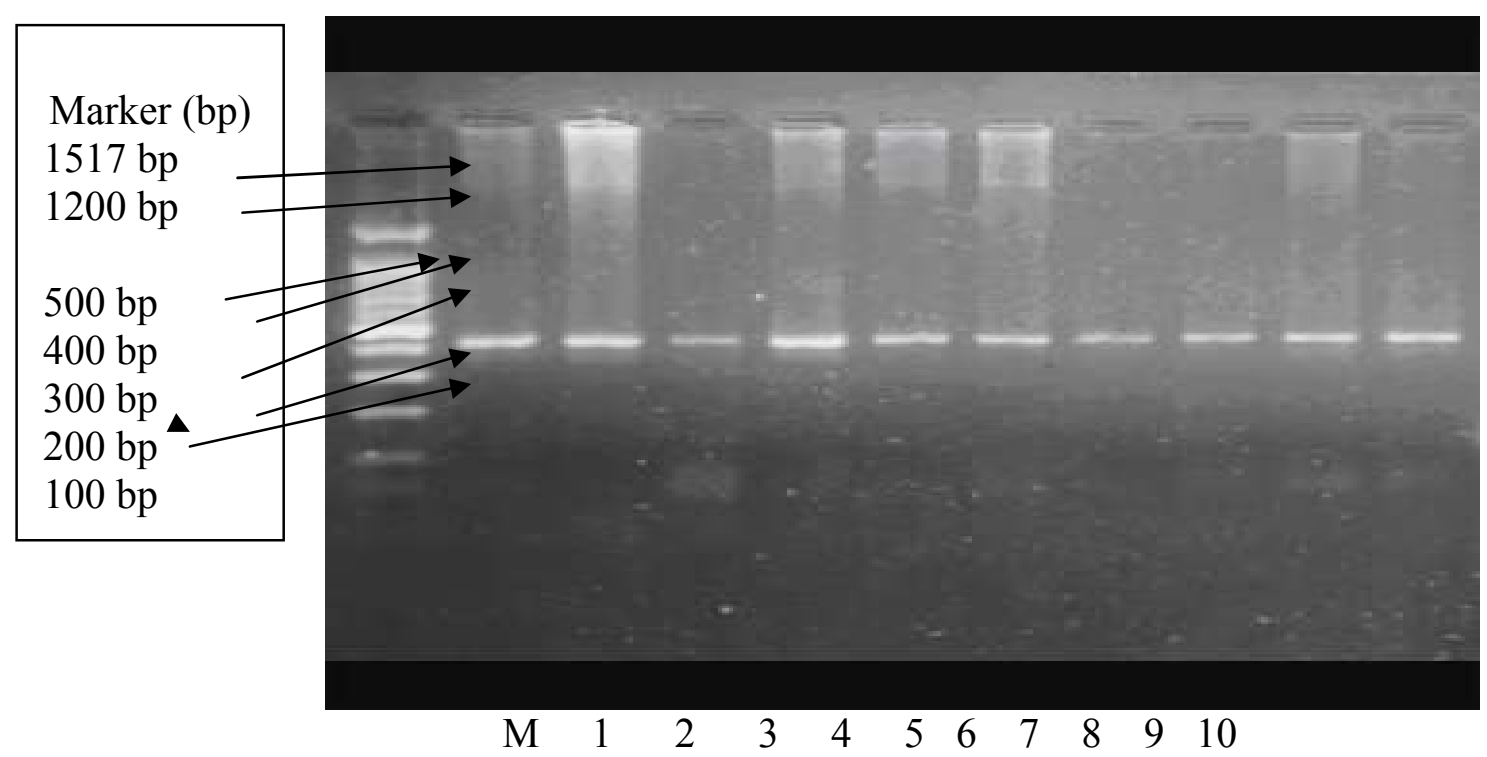

Gambar 1. Hasil Amplifikasi Sampel DNA Sapi Madura di Pamekasan Menggunakan Primer Ghe5

Hasil amplifikasi dengan primer GHE5F dan GHE5R menunjukkan suatu band pada gel agarose $2 \%$ setelah dilakukan elektroforesis dengan ukuran fragmen $450 \mathrm{bp}$ pada DNA yang teramplifikasi, hal ini berarti bahwa primer GHE5F dan GHE5R yang diadopsi dari Ge et al. (2003) memiliki kesesuaian dengan DNA sapi Madura sehingga dapat digunakan untuk mengamplifikasi DNA sapi Madura. Primer GHE5F dan GHE5R dilaporkan oleh (Rahayu et al., 2006) juga memiliki kesesuaian dan dapat digunakan untuk mengamplifikasi gen growth hormon sapi Bali.

DNA hasil PCR (PCR produk) selanjutnya digunakan sebagai meteri untuk mengidentifikasi polimorfisme genetik individu-individu sapi sampel yang dilakukan dengan teknik RFLP, dipotong menggunakan enzim HaeIII.

\section{Penentuan Polimorfisme}

Polimorfisme genetik sering digunakan untuk mengkarakterisasi individu-individu ternak yang selanjutnya dapat juga dihubungkan dengan sifat-sifat fenotipik yang dituju. Hasil elektroforesis gel agarosa $2 \%$ pada DNA PCR produk yang telah dipotong menggunakan enzih HaeIII dengan teknik RFLP ditunjukkan pada Gambar 2. 


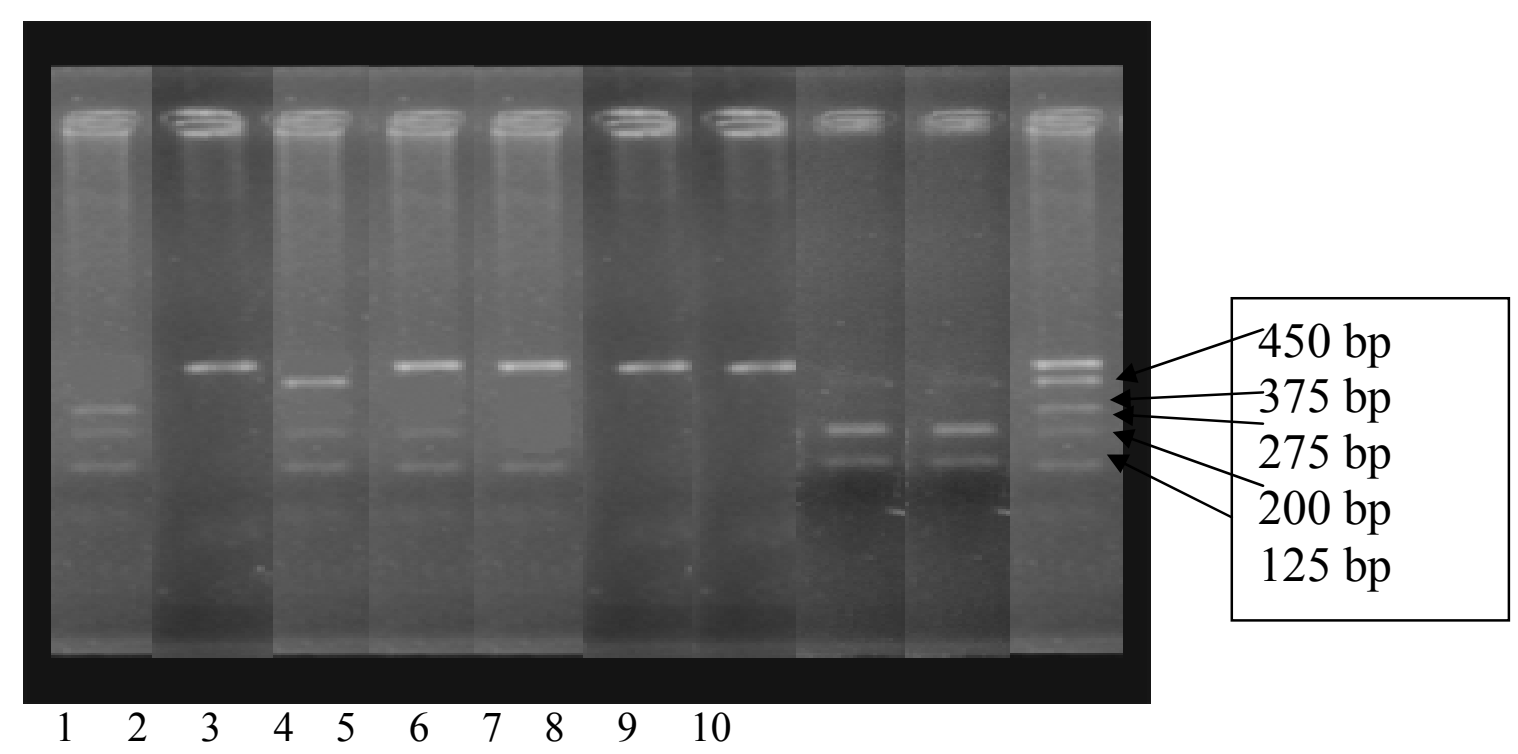

Gambar 2. Bentuk Pita DNA Marker Kandidat Gen Pertumbuhan Sapi Madura di Pamekasan Hasil Pemotongan Menggunakan Enzim Haeiii

PCR produk yang dipotong dengan enzim HaeIII menghasilkan 5 fragmen pemotongan DNA dengan pasangan basa 450bp, 375bp, 275bp, 200bp dan 125bp. Sapi sampel memiliki pola pemotongan pada fragmen yang berbeda-beda (Tabel $1)$.

Hasil pemotongan menggunakan enzim HaeIII menghasilkan perbedaan pemotongan pita DNA, Albert et al.
(1989) menyatakan bahwa apabila terdapat variasi dalam sekuen DNA yang dapat dideteksi sebagai perbedaan antara individu dalam populasi. Jika perbedaan itu jarang ditemui disebut mutasi, namun jika sering ditemui disebut polimorfisme. Sesuai dengan pernyatakan tersebut, pada hasil pemotongan DNA sapi Madura di Pamekasan menggunakan enzim HaeIII terdapat polimorfisme genetik.

Tabel 1. Posisi Basa yang Terpotong Ddngan Teknik PCR-RFLP Menggunakan Enzim Haeiii pada Sapi Madura di Pamekasan

\begin{tabular}{cccccc}
\hline \hline & \multicolumn{5}{c}{ Posisi Pemotongan Fragmen (bp) } \\
\cline { 2 - 6 } No Sampel & 450 & 375 & 275 & 200 & 125 \\
\hline 1 & - & - & $\mathrm{x}$ & $\mathrm{x}$ & $\mathrm{x}$ \\
2 & $\mathrm{x}$ & - & - & - & - \\
3 & - & $\mathrm{x}$ & - & $\mathrm{x}$ & $\mathrm{x}$ \\
4 & $\mathrm{x}$ & - & - & $\mathrm{x}$ & $\mathrm{x}$ \\
5 & $\mathrm{x}$ & - & - & - & $\mathrm{x}$ \\
6 & $\mathrm{x}$ & - & - & - & - \\
7 & $\mathrm{x}$ & - & - & - & - \\
8 & - & - & - & $\mathrm{x}$ & $\mathrm{x}$ \\
9 & - & - & - & $\mathrm{x}$ & $\mathrm{x}$ \\
10 & $\mathrm{x}$ & $\mathrm{x}$ & $\mathrm{x}$ & $\mathrm{x}$ & $\mathrm{x}$ \\
\hline
\end{tabular}

Keterangan : $\mathrm{x}$ : terjadi pemotongan

- : tidak terjadi pemotongan 
Polimorfisme genetik ditunjukkan dengan adanya 4 macam tipe pemotongan atau haplotipe (Tabel 2). Haplotipe I dengan 1 fragmen, haplotipe II dengan 2 fragmen, haplotipe III dengan 3 fragmen dan haplotipe IV dengan 5 fragmen.

Tabel 2 menunjukkan bahwa pada sapi Madura di Pamekasan terdapat variasi genetik gen pertumbuhan hasil pelacakan menggunakan teknik PCRRFLP dengan jumlah haplotipe 4 . Haplotipe 2 memiliki 2 ( 2 a dan 2 b) sub- haplotipe, haplotipe 3 memiliki 3 (3a, 3b dan 3c) sub-haplotipe. Haplotipe 1, tidak terjadi pemotongan yang ditunjukkan dengan ukuran fragmen $450 \mathrm{bp}$. Haplotipe 2 , terjadi pemotongan dengan ukuran fragmen (2a) 125bp dan $450 \mathrm{bp}$ (2b) 125bp dan 200bp. Haplotipe 3 dengan ukuran fragmen (3a) 125bp, 200bp dan 450bp (3b) 125bp, 200bp dan 375bp (3c) 125bp, 200bp dan 275bp. Haplotipe 4 dengan ukuran fragmen $125 \mathrm{bp}, 200 \mathrm{bp}$, $275 \mathrm{bp}, 375 \mathrm{bp}$ dan $450 \mathrm{bp}$.

Tabel 2. Polimorfisme Genetik Sapi Madura Di Pamekasan Hasil PCR-RFLP

\begin{tabular}{ccccccccc}
\hline \hline Haplotipe & Sub- & Frekuensi & \multicolumn{7}{c}{ Posisi Fragmen } \\
\cline { 5 - 9 } & haplotipe & $(\%)$ & 450 & 375 & 325 & 275 & 200 & 125 \\
\hline I & - & $3 / 10(30)$ & $\mathrm{x}$ & - & - & - & - & - \\
II & $2 \mathrm{a}$ & $1 / 10(10)$ & $\mathrm{x}$ & - & - & - & - & $\mathrm{x}$ \\
& $2 \mathrm{~b}$ & $2 / 10(20)$ & - & - & - & - & $\mathrm{x}$ & $\mathrm{x}$ \\
$\mathrm{III}$ & $3 \mathrm{a}$ & $2 / 10(20)$ & $\mathrm{x}$ & - & - & - & $\mathrm{x}$ & $\mathrm{x}$ \\
& $3 \mathrm{~b}$ & $1 / 10(10)$ & - & $\mathrm{x}$ & - & - & $\mathrm{x}$ & $\mathrm{x}$ \\
& $3 \mathrm{c}$ & $1 / 10(10)$ & - & - & - & $\mathrm{x}$ & $\mathrm{x}$ & $\mathrm{x}$ \\
$\mathrm{IV}$ & - & $1 / 10(10)$ & $\mathrm{x}$ & $\mathrm{x}$ & - & $\mathrm{x}$ & $\mathrm{x}$ & $\mathrm{x}$ \\
\hline
\end{tabular}

Keterangan : $\mathrm{x}$ : terjadi pemotongan - : tidak terjadi pemotongan

\section{Ekspresi Fenotipik (PBB) Sapi Madura di Pamekasan pada Haplotipe yang Berbeda}

Seberapa jauh perbedaan haplotipe terekspresi dalam pertambahan bobot badan sapi Madura di Pamekasan dapat dilihat pada Tabel 3.

Tabel 3. Ekspresi Fenotipik (PBB) Sapi Madura di Pamekasan pada Haplotipe yang Berbeda

\begin{tabular}{ccc}
\hline \hline Haplotipe & Sub-Haplotipe & $\begin{array}{c}\text { Pertambahan Bobot Badan } \\
(\mathrm{kg} / \mathrm{hari})\end{array}$ \\
\hline I & - & 0,048 \\
II & $2 \mathrm{a}$ & 0,112 \\
& $2 \mathrm{~b}$ & 0,107 \\
III & $3 \mathrm{a}$ & \\
& $3 \mathrm{~b}$ & 0,036 \\
& $3 \mathrm{c}$ & 0 \\
IV & - & \\
\hline
\end{tabular}

Tabel 3 menunjukkan bahwa haplotipe II (sub-haplotipe 2a) dan haplotipe III (sub-haplotipe $3 \mathrm{~b}$ dan 3c) menunjukkan pertambahan bobot badan yang paling tinggi. Haplotipe IV mengekspresikan pertambahan bobot badan yang paling rendah. 
Penelitian yang dilakukan oleh Dybus (2002) dengan jumlah sampel yang mendekati 2000, penggunaan gen hormon pertumbuhan dan enzim restriksi (MspI) menghasilkan pola alel dominan resesif yang mampu membedakan sapisapi perah dengan produksi susu yang tinggi dan rendah. Meskipun penampilan fenotip untuk bobot badan pada sapi dipengaruhi oleh banyak faktor, tetapi semua sifat yang tampak (fenotip) dipengaruhi oleh informasi genetik yang dibawa oleh DNA, sehingga variasi DNA berhubungan dengan variasi fenotip (Sutarno, 2005).

\section{KESIMPULAN}

Disimpulkan bahwa dengan jumlah sample yang terbatas sudah mulai ditunjukkan adanya kecenderungan marka spesifik untuk sifat pertumbuhan sapi Madura, meskipun hubungan tersebut belum nyata. Dengan meningkatnya jumlah sample serta penggunaan primer dan ensim restrik yang tepat dimungkinkan akan diperoleh marka genetik yang lebih spesifik sehingga dapat digunakan sebagai dasar pelaksanaan seleksi.

\section{DAFTAR PUSTAKA}

Albert, B., D. Bray, J. Lewis, M. Raff, K. Roberts dan J. D. Watson. 1989. Molecular Biology of the Cell. Garland Publishing. Inc. New York, USA

Dybus, A. 2002. Association of growth hormone (gh) and prolactin (prl) genes polymorphisms with milk production traits in polish blackand-white cattle. J. Anim. Sci. 20(4):203-212.
Ge W., Davis ME, Hines HC, Irvin KM dan R.C.M. Simmen. 2001. Association of a genetic marker with blood serum insulin-like growth factor-i concentration and growth traits in angus cattle. J. Anim. Sci. 79: 1757-1762.

Ge W, Davis ME, Hines HC, Irvin KM dan R.C.M. Simmen. 2003. Association of single nucleotide polymorphisms in the growth hormone and growth hormone receptor genes with blood serum insulin-like growth faktor i concentration and growth traits in angus cattle. J. Anim. Sci. 81: 641648.

Rahayu, Sri, S.B. Sumitro, T. Susilawati dan Soemarno. 2006. Identifikasi Polimorfisme Gen Growth Hormone Sapi Bali dengan Metode PCR-RFLP. Universitas Brawijaya, Malang.

Robyt, I. M. dan B. J. White.1987. Biocemichal Tecniques: Theory and Practices. Brooks/Cole Publishing Company, California.

Sutarno. 2005. Penyulihan Asam Amino Leucin oleh Valin pada Posisi 127 Gen Penyandi Hormon Pertumbuhan dan Pengaruhnya terhadap Pertumbuhan Sapi Benggala. http://www.Jvetunu. com diakses 23 Maret 2006.

Suyadi, N. Isnaini dan S. Rahayu. 2005. Preseleksi kemampuan produksi daging sapi Madura berdasarkan marka gen kandidat untuk sifat pertumbuhan. Laporan RUT XII-1.

Suyadi, 2005. Bioteknologi Reproduksi dan Peranannya dalam Peningkatan Mutu Genetik dan Produktivitas Ternak. Pidato Pengukuhan Guru Besar. Universitas Brawijaya, Malang. 